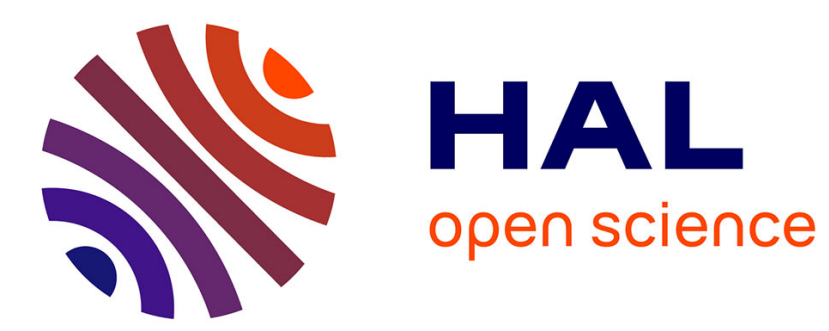

\title{
Clitic Doubling and Contact in Arabic
}

Lameen Souag

\section{To cite this version:}

Lameen Souag. Clitic Doubling and Contact in Arabic. Zeitschrift für arabische Linguistik $=$ Journal of Arabic linguistics $=$ Journal de linguistique arabe, 2017, 66, pp.45-70. 10.13173/zeitarabling.66.0045 . halshs-01966339

\section{HAL Id: halshs-01966339 \\ https://shs.hal.science/halshs-01966339}

Submitted on 21 Jul 2021

HAL is a multi-disciplinary open access archive for the deposit and dissemination of scientific research documents, whether they are published or not. The documents may come from teaching and research institutions in France or abroad, or from public or private research centers.
L'archive ouverte pluridisciplinaire HAL, est destinée au dépôt et à la diffusion de documents scientifiques de niveau recherche, publiés ou non, émanant des établissements d'enseignement et de recherche français ou étrangers, des laboratoires publics ou privés. 


\section{Offprint from:}

Zeitschrift für Arabische Linguistik Journal of Arabic Linguistics Journal de Linguistique Arabe

Herausgegeben von/Edited by / Edité par Werner Arnold, Otto Jastrow

66 (2017)

Harrassowitz Verlag $\cdot$ Wiesbaden 
Beratendes Herausgebergremium/Editorial Board/Editeurs consultatifs:

J. Aguadé (Cádiz), A. Bloch (Berkeley), H. Bobzin (Erlangen), A. Denz (München), H. Grotzfeld (Münster), M. Hegazi (Kairo), S. Procházka (Wien), Sh. Talay (Berlin)

Manuskripte und Rezensionen werden erbeten an:

Please address manuscripts and book reviews to:

Prof. Dr. Werner Arnold

Universität Heidelberg,

Seminar für Sprachen und Kulturen des Vorderen Orients, Semitistik,

Schulgasse 2, 69117 Heidelberg, Germany

Tel. +49(0)6221/542957, Fax +49(0)6221/543401

E-Mail: arnold@uni-hd.de

Diese Zeitschrift kann auch in elektronischer Form über JSTOR (www.jstor.org)

bezogen werden

This journal can also be accessed electronically via JSTOR ( $w$ ww.jstor.org).

Informationen zum Verlagsprogramm finden Sie unter

http://www.harrassowitz-verlag.de

For further information about our publishing program consult our website

http://www.harrassowitz-verlag.de

(c) Otto Harrassowitz GmbH \& Co. KG, Wiesbaden 2017

Die Zeitschrift und alle in ihr enthaltenen Beiträge sind urheberrechtlich geschützt. Jede Verwertung außerhalb der engen Grenzen des Urheberrechtsgesetzes ist ohne Zustimmung des Verlages unzulässig und strafbar. Das gilt insbesondere für Vervielfältigungen jeder Art, Übersetzungen, Mikroverfilmungen und für die Einspeicherung in elektronische Systeme.

Satz: Friederike Busse, Jonathan Reich

Gedruckt auf alterungsbeständigem Papier.

Druck und Verarbeitung: Hubert \& Co., Göttingen

Printed in Germany

ISSN 0170-026X 


\section{Inhalt}

\section{Aufsätze}

M. VAN PUTTEN: The illusory Yemenite connection of Andalusi Arabic........................................................................ 5

L. SOUAG: Clitic doubling and language contact in Arabic..................... 45

Y. B. ALBADER: Polysemy and Semantic Change in the Arabic Language and Dialects.

\section{Buchbesprechung}

S. HOPKINS: George Borrow's Moorish vocabulary (Tangiers 1839). Edited with an introduction and notes by Simon Hopkins.

(J. Aguadé) 101 



\title{
Clitic doubling and language contact in Arabic
}

\author{
Lameen Souag*
}

\begin{abstract}
Forms of clitic doubling are attested in a significant number of Arabic varieties, including the Levant and northern Iraq, parts of Algeria and Morocco, Malta, Central Asia, and even, doubtfully, Dhofar. Language contact is widely accepted as an explanation for its presence in the Levant, and has been advanced as an explanation for its occurrence in North Africa, Malta, and Central Asia. However, none of the contact explanations proposed have yet addressed this phenomenon's overall distribution across all of Arabic, usually limiting themselves to one or two regions at a time, and few have examined the parameters along which the relevant constructions vary. Without such an overview, it is not possible to exclude the hypothesis that clitic doubling simply reflects Arabic-internal trends, nor to determine whether its distribution reflects a single innovation or multiple independent ones. Updating the pioneering work of A. FISCHER (1907; 1909), this article demonstrates that clitic doubling has arisen independently within Arabic at least four times under the influence of different substrata/adstrata, and suggests areas in which more data on this construction would be especially useful.
\end{abstract}

\section{Introduction}

Clitic doubling is best known in Arabic for Levantine dialects (AOUN 1993), and is described only for those dialects in the Encyclopedia of Arabic Language and Linguistics (AOUN 2011). Nevertheless, forms of clitic doubling are reported in at least five other widely separated varieties: parts of Algeria and Morocco (HEATH 2002; MARÇAIS 1977), Malta (ČÉPLÖ 2011), Central Asia (VINNIKOV 1969), and Dhofar in Oman (RHODOKANAKIS 1908). At first sight, the multiple, mutually independent attestations suggest that this

* Lameen Souag, LACITO (CNRS, Paris III, Inalco), 7, rue Guy Môquet (bât. D), 94801 Villejuif Cedex, France. 
development emerges naturally Arabic-internally from universal structural tendencies (BOSSONG 1998), calling into question efforts to explain it in terms of Aramaic contact (FÉGHALI 1928); even the strongly substratist account of CONTINI (1999: 111) finds that the case of Dhofar, in particular, poses difficulties for a substrate explanation. However, this impression derives from insufficiently detailed descriptions. Closer examination reveals that the contexts for, and forms of, clitic doubling differ widely among these dialects, and that the differences correspond closely to differences among the clitic doubling constructions of languages with which these dialects have been in contact. This indicates that clitic doubling is neither a recurring Arabic-internal development nor a monolithic retention from an Aramaic substratum, but a collective label for several different developments, most but not all triggered by language contact.

\subsection{Definition}

For current purposes, clitic doubling - a term widely used since JAEGGLI (1982) - will be defined as the co-occurrence of a (pleonastic) anaphoric marker with a coreferential noun phrase within the same predicate expressing the same argument. Unlike earlier terms such as "pleonastic pronouns" or "object reduplication", this definition excludes dislocated or hanging topics, in which a "pleonastic" pronoun is used almost everywhere irrespective of its grammaticality in other contexts. It also has the advantage of excluding subjects, with which the verb agrees in almost every Arabic variety. A prototypical illustration of the phenomenon is the following Lebanese Arabic sentence, from AOUN (1993):
1) hikēe-lo
told.3MSg-3MSgDat
la-sāmi ḥkēye
he told Sami a story
to-Sami story

This might more literally be rendered as "he told to him, to Sami, a story"; the pleonastic anaphoric marker lo "to him" is coreferential with the noun phrase "Sami", and must form part of the same predicate since it intervenes between the non-dislocated object and the verb.

Clitic doubling is, of course, not a uniquely Arabic phenomenon; it is attested worldwide (ARKADIEV 2010), and is widespread in the Mediterranean, where has been studied in rather greater depth for languages such as Spanish (SUÑER 1988) and Greek (ANAGNOSTOPOULOU 1999; KALLULLI 2001). Wherever it is attested, we often find that a given sentence is equally grammatical with or without clitic doubling, giving the impression of op- 
tionality. However, closer investigation typically reveals that even in such languages clitic doubling is rule-governed; in general, the possibility of clitic doubling is determined by how high the argument in question stands on the definiteness and animacy scales, allowing clitic doubling to serve as a type of Differential Object Marking (MORIMOTO 2002). At the extreme, as more and more restrictions on clitic doubling are dropped, it may develop into agreement (GIVÓN 1976; GELDEREN 2011).

It should thus be clear that clitic doubling describes a family of similar constructions, not a specific construction. To specify a given clitic doubling construction in a given variety more precisely, the following parameters all turn out to be relevant:

1. which class(es) of heads allow or require their arguments to be doubled?

2. which of their argument(s) may be doubled?

3. what portion of the definiteness and animacy scales may this argument occupy?

4. which "dummy" case assigner, if any, governs the doubled nominal?

\subsection{Previous work}

There is a long tradition of explaining clitic doubling in Arabic in terms of substratum influence. A. FISCHER (1907; 1909), endorsed by BROCKELMANN (1982: 243), already pointed to the important similarities in doubling between Maghrebi Arabic and Berber on the one hand, and Levantine Arabic and Syriac on the other, which he took to derive in each case from the respective substratum. AQUILINA (1959:347) lists "pleonastic use of the direct and indirect pronoun" in Maltese as an example of Italian influence, without presenting arguments. MARÇAIS (1977:171) reaffirmed A. FISCHER'S claim that the Maghrebi construction was a calque from Berber. DIEM (1979:47-48) expanded on A. FISCHER'S suggestion, arguing that direct object and possessor doubling represents substratum influence in Iraq and the Levant, and that similar constructions in the Maghreb and Malta were brought over from Iraq and Syria, with possible Berber influence on possessor doubling (ibid:54). CONTINI (1999) provides further evidence in support of a substratum explanation in Iraq and the Levant, and tentatively suggests Sicilian influence in Maltese, while noting the difficulty of explaining clitic doubling in Dhofar in substrate terms. CHIKOVANI (2002: 255-256; 2003: 6-7; 2005: 132-133) and RATCLIFFE (2005) are two of the several authors to have pointed out that possessive doubling in Central Asian Arabic may be explained as the result of Turkic or Persian influence. More recent reaffirmations of the role of Aramaic substratum influence in 
the development of Levantine/Iraqi clitic doubling are found in WENINGER (2011), COGHILL (2014).

However, these suggestions have remained controversial, and not without reason. Clitic doubling is fairly widely attested cross-linguistically, including in languages that have not been in contact with one another. A priori, the wide spread of clitic doubling might seem to suggest that it reflects a system-internal trend within Arabic. To test for this possibility, it is necessary to consider data from all regions at the same time, rather than limiting one's analysis to a specific region in which prior substrata might coincidentally have mirrored system-internal trends. Moreover, some attested cases of doubling have not so far been explained in terms of contact in the existing literature, notably Dhofar, while others have not previously been described; one of the latter, Dellys (Algeria), will be discussed here. The scepticism towards a contact explanation shown by HEATH (2015: 26-27), NAÏM (2011), or KOUTSOUDAS (1967), and the reservations of BOUCHERIT (1999), are thus understandable. The key to this problem lies going beyond the somewhat misleading catchall label "clitic doubling" to look at the specific characteristics of each construction involved, both in Arabic and in the putative substrata/superstrata.

\section{Clitic doubling by area}

Clitic doubling is well-attested in the Levant and the Maghreb and their fringes, with a more dubious attestation from Oman. The attestations fall most naturally into five groups: the Levant and northern Iraq, Cyprus, Central Asia, the northwestern Maghreb, and Malta.

\subsection{Levant}

Much the best-studied part of the Arab world for clitic doubling is the Levant; LANDBERG (1883: 67), FÉGHALI (1928: 210, 362), COWELL (1964: 435), KOUTSOUDAS (1967), ABU-HAIDAR (1979: 103-104), AOUN (1981; 1993; 1999), LEVIN (1987), SHLONSKY (1997: 185-205), CONTINI (1999), and BRUSTAD (2000) are just some of the most prominent works to discuss the phenomenon for this region. Alongside the Levant proper, clitic doubling is also well-attested in the Arabic dialects of northern Iraq, with a very similar distribution. (The historically linked case of Cyprus requires separate examination.) In most of this region, clitic doubling is common in sedentary varieties, though unattested in Bedouin ones. The specific constructions involved turn out to show peculiarities almost unparalleled within the Arab world outside this region. 
The most comprehensive syntactic description available is that of AOUN, for the dialect of Beirut. In his variety, doubling may optionally affect any syntactic type of complement: direct objects ( $\check{s} e \bar{f}-o$ la-sāmi "he saw Sami"), indirect objects (hikēelo la-sāmi ḩkēye "he told Sami a story"), possessors (ktēb-o la-sāmi "Sami's book"), and even objects of prepositions ${ }^{1}\left(m a^{c}-o\right.$ lasāmi "with Sami"). A rarer alternative strategy for possessors not mentioned by AOUN effectively treats the normal analytic genitive particle $t a b a^{c}$ as a preposition: əs-speech tabac-o la-Nașralla "Nasrallah's speech" (Marie-Aimé Germanos, p.c., from corpus). In every case, the doubled nominal is marked with a case assigner $l a$-, which elsewhere means "to", while the pronominal affix doubling it appears in its normal position. The doubled element is normally definite, and obligatorily specific. Doubling of the objects of preposition is rarely reported for other Levantine varieties, but otherwise this agrees with most descriptions of sedentary Levantine varieties, although geographical and social factors affect its frequency: the pragmatic restrictions on doubling seem to be tighter as one goes further south within Palestinian Arabic (cf. LEVIN 1987), and doubling of possessors is considered by NAÏM (2009) as more frequent in youth speech.

The function of this construction has proved harder to identify, and most descriptions make no attempt to do so. COWELL (1964: 435) identifies it for Syrian Arabic as an "inverted topic" construction used with reference to human beings, and distinguishes it from ordinary comment-topic inversion with extraposition of the topic explicitly by the preposition la- and implicitly by the lack of a comma. LEVIN (1987: 36) suggests that, in northern Palestinian varieties, it is used when the subject or the act is stressed (focused) or to emphasise an emotional attitude (such as sorrow, pity, wonder, impatience, mistrust) towards what is expressed (reprimanding students for not doing their homework, or breaking things). BRUSTAD (2000: 355, 358) instead assigns to clitic doubling in Syrian Arabic the function of "recall[ing] or reinvok[ing] a highly individuated entity from either the permanent or the conversational registry into discourse topic", motivated "perhaps because it has not been active in the conversational registry, or perhaps because the speaker believes that the interlocutor has forgotten about it", as well as to disambiguate the respective roles of addresser and addressee.

Such clitic doubling, with a dummy case assigner la-, has a long history in the Levant. FÉGHALI (1928: 210, 362) suggested that it was more fre-

1 Clitic doubling is reportedly much more pragmatically restricted in this context than in the others mentioned (SAMIA NAÏM, p.c.); AOUN does not address the contexts of usage of these forms in any detail. 
quent in the Arabic of $9^{\text {th }}$ century Maronite manuscripts than in modern Lebanese Arabic, and BLAU (1967) finds examples in Christian Palestinian manuscripts of the first millennium $\mathrm{AD}$ (though he remains agnostic on whether this influence was mediated via spoken Arabic of the time or was simply due to excessively literal translation from Aramaic texts):

2)

\begin{tabular}{|c|c|c|c|}
\hline$f a-q \bar{a} l-\bar{u}$ & $l a-h u$ & l-'abbahāt & li-d̄ālika \\
\hline
\end{tabular}

'et les pères ont dit à ce laïc' (BLAU 1967: 395)

The corresponding construction is also attested in the qaltu-dialects of northern Iraq and Baghdad, as well as Muslim Baghdad Arabic, a gilit-dialect. It has attracted less attention in this region, but relevant work includes ERWIN (1963), MALAIKA (1963: 64), BLANC (1964: 128-132), ABUHAIDAR (1991: 116), JOHNSTONE (1975: 107-108), JASTROW (1979: 49; 1988: 55; 1990: 72-74), MELCER (1995). As in the Levant, it normally uses a case assigner $l$ - irrespective of syntactic role; however, Mosul occasionally allows doubling of direct objects without $l$, while Jewish Arbil and Aqra consistently do so:

3) $a b n-a$

$k-i h a b b-a$

mart-u

son-3FSgGen

PROG-love.Impf.3FSg woman-3MSgGen

Her son loves his wife. (Aqra; JASTROW 1990: 72)

JASTROW (1990: 72-74) comments that doubling occurs only for definites, but otherwise definiteness-related restrictions on doubling remain undescribed for this region. All varieties seem to allow doubling of direct objects, but doubling of indirect objects is explicitly mentioned only for Baghdad and Mosul, while doubling of objects of prepositions is reported only for Baghdad. Possessor doubling is described only in Baghdad, but is wellattested there, and, as in the Levant, uses $l$ - rather than the dialect's normal analytic genitive particle māl. BLANC (1964) indicates a preference for doubling with kinship terms, which would be unique in the region, but ABUHAIDAR (1991: 116) does not confirm this, giving the example la'abəm lalawlèd "the children's toys", while MELCER (1995: 75) indicates that only four out of the seven examples of possessor doubling in his corpus involved kinship terms. This feature is attested in Baghdad almost as early as in the 
Levant proper: LEVIN (1987) quotes the $14^{\text {th }}$ century Baghdad dialect poet Al-Hillī's line $m \bar{a}$ 'āšiqhā li-šakar "he did not love Shakar"2.

The dominant vernacular of both the Levant and Iraq region before the spread of Arabic was Aramaic, in a number of varieties of which probably the best attested is Syriac. Direct object doubling with and without $l$ - has a long history in Aramaic, already attested before $70 \mathrm{AD}$ in the Dead Sea Scrolls (SCHATTNER-RIESER 2004: 112). In Syriac, definite direct objects may be doubled with or without $l$ - (JOOSTEN 1996: 40), and definite indirect objects may be doubled with $l$ - (ibid: 45-46):

\section{4) $b n \bar{a}-y(h) i \quad$ (l-)bayt $\bar{a} \bar{a}$ \\ build.Pf.3MSgAcc (to-)house \\ "He built the house." (NÖLDEKE 1904:227, COGHILL 2014)}

Such doubling occurs predominantly with human referents or textually prominent inanimates, but may also mark the endpoint of a sequence of closely related clauses (KHAN 1984: 473, 482). Based on these parallels, A. FISCHER (1909: 825) already described the Levantine Arabic clitic doubling construction as undoubtedly of Aramaic origin, and FÉGHALI (1928) argues the same, strongly supported by CONTINI (1999).

However, important differences must also be noted. In possessor doubling, from the Imperial Aramaic of the late $5^{\text {th }}$ century BC to the Syriac of the early medieval period, the case assigner is almost always genitive $d$ (WHITEHEAD 1978: 130; MURAOKA 1998: 234; JOOSTEN 1996: 50). Possessor doubling with $l$ - is attested in Aramaic, almost always with the head noun "name", but is vanishingly rare, and apparently arises from analogy with object doubling (HOPKINS 1997). DIEM (1976) points out that the genitive marker in modern Western Neo-Aramaic derives from $l$ - rather than $d$ (CORRELL 1978: 6), bringing the Aramaic construction closer to the Levantine Arabic one, but this still leaves the construction's presence in Iraq problematic: it is not reported in Eastern Neo-Aramaic, and the only reported evidence for a genitive $l$ - there is a single attestation in Mandaic (HOPKINS 1997: 29), well outside the region where doubling is attested today. Moreover, Syriac also allows doubling of the objects of prepositions, but there too the case assigner is another copy of the preposition, not $l$ - (JOOSTEN

2 The use of $l$ - as a marker of the direct object is attested here even earlier than doubling, being specifically described as characteristic of the Baghdad dialect by al-Wāhidī as early as the $11^{\text {th }}$ century (BLANC 1964). 
1996: 45-46). These facts makes it difficult to take the Levantine and Iraqi Arabic construction as a simple copy of the attested Syriac one.

The relatively detailed analyses available for Levantine Arabic doubling make a better explanation possible. Syntactically, AOUN'S (1993; 1999) work shows, based on binding theory arguments that carry over at least to Palestinian Arabic (MOHAMMAD 2000: 78), that in doubled complements only the clitic occupies an argument position; despite appearances, the nominal does not. Semantically, all descriptions that attempt to identify its discourse function - discussed above - indicate that the doubled nominal is normally interpreted as given or topical information. Synchronically, these two facts make it plausible to interpret $l a$ - as a general marker of in situ topicalisation.

The earliest attested Levantine Arabic doubling constructions seem to feature direct and indirect objects alone; for these two categories, Aramaic and Levantine Arabic use the same construction. With these two environments serving as a bridging context, it became possible for Levantine Arabic to reinterpret $l a$ - as a marker of in situ topicalisation combining obligatorily with clitic doubling. Once this reinterpretation was operative, there would no longer have been any reason not to use la- with clitic doubling of possessors or complements of prepositions. In this scenario, the initial stages of the development of clitic doubling in the Levant derive from Aramaic substratum influence, but the current situation also reflects subsequent Arabic-internal developments.

\subsection{Cyprus}

At first, one might expect Cypriot Maronite Arabic to provide a precious window on the history of clitic doubling in Levantine Arabic, due to its undoubted Levantine origins and longstanding isolation from other Arabic varieties. These hopes must be tempered for two reasons: the paucity of data on clitic doubling in this still inadequately described variety, and the profound influence on it of Greek, a language which also makes extensive use of clitic doubling.

In Cypriot Maronite Arabic, $l$ - has followed a rather different path than in the Levant. Animate direct objects are marked with $l$ - (homophonous with the definite article, but distributionally distinct) whether or not doubling is present (BORG 2004: 412), a usage obsolete in modern Levantine dialects but with a long history in Levantine Arabic (BORG 2004: 46-47). Moreover, unlike in Levantine, even pronominal animate direct objects take l-, completing the similarity to datives; contrast rak'á-llu "he hit him" with 
mannírka'a suđrna "we beat our breasts" (BORG 2004: 252). Direct object doubling is attested, but differs from Levantine in two conspicuous respects: the presence or absence of $l$ - on the nominal is in principle independent of doubling, and the presence or absence of $l$ - on the pronominal is determined by animacy rather than by role:

5) kil-ú-x

l-láxm

ate-3Pl-3MSgAcc

the-meat

"they ate up the meat" (BORG 1984: 84)

6) $u$ má-rka'-t-íllu

l-insán ta 'átt

'alé-xa

and not-hit.Pf-2MSg-3MSgDat l-man REL assault.3MSgPf on-3FSg

"but (you did) not (hit) the man who assaulted her?" (BORG 1985: 138)

Direct object doubling is well-attested in Cypriot Greek, as in other Greek varieties:

7) ksero

$\begin{array}{lll}\text { ton } & \text { ton } & \text { yior } \gamma \text { o } \\ \text { him.CL-ACC } & \text { the } & \text { George.ACC }\end{array}$

know.1SG

'I know George.' (CHATZIKYRIAKIDIS 2010: 315)

Neither Levantine Arabic nor Greek perfectly parallels the CMA construction, but Greek matches it perfectly for inanimates, whereas Levantine matches it perfectly neither for animates nor for inanimates, as illustrated by Table 1:

Table 1: A comparison of doubling constructions across Levantine Arabic, CMA, and Greek

\begin{tabular}{|l|l|l|l|}
\hline & Levantine & $\mathrm{CMA}$ & Greek \\
\hline inanimate & $\mathrm{V}-\mathrm{pr}_{\mathrm{x}} l a-\mathrm{X}$ & $\mathrm{V}-\mathrm{pr}_{\mathrm{x}} \mathrm{X}$ & $\mathrm{V} \mathrm{pr}_{\mathrm{x}} \mathrm{X}$ \\
\hline animate & $\mathrm{V}-\mathrm{pr}_{\mathrm{x}} l a-\mathrm{X}$ & $\mathrm{V}-l-\mathrm{pr}_{\mathrm{x}} l-\mathrm{X}$ & $\mathrm{V} \mathrm{pr}_{\mathrm{x}} \mathrm{X}$ \\
\hline
\end{tabular}

CMA direct object doubling is thus better considered as the result of Greek influence, although it cannot be ruled out that parallels in some earlier stage of Levantine Arabic played a role in its development.

Possessor doubling is also attested in this variety, mainly for inalienable possession of kinship terms; the case assigner may be either $l$-, as in the Levant: 
8) ' $a m m-u \quad$ l-zawž-i

uncle-3MSgGen to-husband-1SgGen

“my husband's paternal uncle" (BORG 2004: 412)

or the genitive particle tel < *dēl (BORG 2004: 241), unlike in the Levant:

9) úmm-u

mother-3MSgGen

"my boss's late mother" (BORG 1984: 84) tel-im'állm-i

Gen-boss-1SgGen

These constructions are more historically interesting, since possessor doubling is not well-documented for Greek. The preference for kinship terms in this construction is reportedly paralleled in Baghdad Arabic, and more certainly in early stages of Aramaic (WHITEHEAD 1978: 130). The possibility of possessor doubling with $l$ - suggests that this construction may have been inherited from the pre- $14^{\text {th }}$ century Levantine Arabic which the Maronites brought to Cyprus; on the other hand, the alternative of using tel as the case assigner in a doubling construction does not correspond well to Levantine Arabic, rather suggesting the Aramaic pattern. The observed genitive pattern might be interpreted as reflecting the situation in an early Levantine Arabic variety with more Aramaic substratum influence than most; however, more historical data on the contact situation in Cyprus, and more synchronic data on the distribution of $l / t e l$, would be indispensable to reach a firm conclusion for this dialect.

\subsection{Central Asia}

The scattered Arabic dialects surviving in parts of Uzbekistan and Afghanistan and in northeastern Iran presumably reached their present location from Iraq. Like Cypriot Maronite Arabic, they use an originally dative direct object marker (here $i-<i l \bar{a}$ ) with animates, without regard to the presence or absence of doubling. Heavy influence from Persian and Turkic has led them to adopt default SOV word order, and, while they make heavy use of clitic doubling, it normally occurs in head-final constructions rather than in the head-initial patterns known elsewhere.

In these varieties, doubling is not found in question focus, but is very commonly attested for direct objects, be they indefinite:

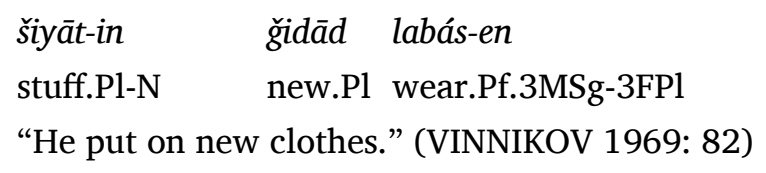

šiyāt-in

ğidād labás-en

stuff.Pl-N

new.Pl wear.Pf.3MSg-3FPl

"He put on new clothes." (VINNIKOV 1969: 82) 
11) sakina xadä-ha

knife take.Pf.3MSg-3FSgAcc

"he took a knife" (Arabkhana: RATCLIFFE 2005: 144)

or definite:

12)
dếw kálb-u
$m \bar{a}-s ̣ o r$
demon heart-3MSgGen Neg-became
'i-wálad-u ta-yíktil-u
SBJ-kill.Impf.3MSg-3MSgAcc
DOM-son-3MSgGen

The demon's heart did not want to kill his (own) son. (VINNIKOV 1969: 81)

The dominant languages of the region, Persian/Tajik and Uzbek, provide an obvious model for SOV order, but not for direct object doubling. Nevertheless, the connection is clear. In Classical Arabic, and in most Arabic dialects, a preverbal object is normally a dislocated topic, whose expected place within the predicate is marked by a clitic pronoun:

$$
\begin{aligned}
& \text { al-kitāb-u } \\
& \text { the-book-NOM } \\
& \text { The book, I took. }
\end{aligned}
$$$$
\text { 'axad-tu-hu }
$$$$
\text { take.PF-1Sg-3MSgAcc }
$$

Rather than directly calquing the SOV order of the region's dominant languages, the Arabs of Central Asia copied its pragmatics to this inherited construction, reinterpreting the former left dislocated topic as an in situ object within the predicate. As a result, direct object clitic doubling became far commoner in these varieties than in any Arabic variety outside Central Asia - but contrasts with Levantine Arabic in its distribution, in its complement restrictions, and in its null case assigner.

The other context in which doubling occurs here is in genitives. Possessors normally follow the possessed, as in Arabic, but in the Uzbekistan varieties occasionally the opposite order is attested, as in Turkic; in the latter case, doubling is obligatory:

$$
\begin{aligned}
& \text { walad-ak faras- } u \\
& \text { boy-2MSgGen } \\
& \text { "your boy's horse" (Qashqa-Darya: CHIKOVANI 2005: 132) }
\end{aligned}
$$


15)

$$
\begin{aligned}
& \text { amir wald- } u \\
& \text { prince son-3MSgGen } \\
& \text { "the prince's son" (Arabkhana: RATCLIFFE 2005: 147) }
\end{aligned}
$$

No examples of doubling were noted in other syntactic contexts.

The doubled possessor construction can more easily be interpreted as a calque, in light of exactly parallel constructions not only in Uzbek (POPPE 1962: 11, 174) but - possibly as a result of Uzbek influence - in the Tajik dialect of Bukhara as well (IDO 2007: 1, 83-84). In both, prenominal genitives are well-attested (obligatory in Uzbek), and the possessed always takes a pronominal suffix agreeing with the possessor:

$\begin{array}{lll}\text { Bukharan Tajik: } & \text { Buxoro } & \text { Universitet-ash } \\ \text { Uzbek: } & \text { Buxoro } & \text { Universitet-i } \\ & \text { Bukhara } & \text { University-3SgGen } \\ & \text { "Bukhara University" (IDO 2007: 1) }\end{array}$

This construction, of course, is unparalleled elsewhere in Arabic.

It thus appears that the doubling constructions found in Central Asian Arabic have no discernible connection to those found in Levantine Arabic; instead, they result exclusively from Persian and Turkic influence, accommodated in part through the reinterpretation of pre-existing topicalisation constructions.

\subsection{Maghreb}

The commonly used division of Maghrebi dialects into "Hilalian" varieties, brought by Bedouins starting from the $11^{\text {th }}$ century, and "pre-Hilalian" varieties, mainly in and around urban areas (MARÇAIS - GUIGA 1925), turns out to be rather useful in understanding the distribution of clitic doubling in this region. Clitic doubling has been reported in the Maghreb (excluding Malta) only in certain pre-Hilalian varieties of Algeria (Skikda, Jijel, Dellys, Nedroma) and Morocco (widespread in the north and the Jbala; attested in the older urban varieties of Rabat, Fez, and Mogador.) All of these are located at or near the edge of large regions that are Berber-speaking to this day. The earliest explicit description of clitic doubling in this region seems to be that of LUCIANI (1889), for the Skikda region; W. MARÇAIS (1902: 204) described it in more detail for Tlemcen. Other discussions include A. FISCHER (1907), HARRELL (1962: 202), P. MARÇAIS (1936: 1052; 1952: 421; 1977: 170), OSTOYA-DELMAS (1938: 81), BOUCHERIT (1999), HEATH (2002: 463), SOUAG (2005: 164), and GUELLA (2011: 6). 
The best-attested type of clitic doubling in this region is limited to a rather specific context: kinship term + pronominal clitic - genitive particle (variously $d, d y \bar{a} l, d i, l i, n t \bar{a}^{c}, t \bar{a}^{c} \ldots$ ) - possessor, (Dellys, author's data):

$\begin{array}{lll}\text { yəmmā-ha } & n t \bar{a}^{c} & b \bar{a} y a \\ \text { mother-3FSgGen } & \text { of } & \text { Baya }\end{array}$

Baya's mother

18)

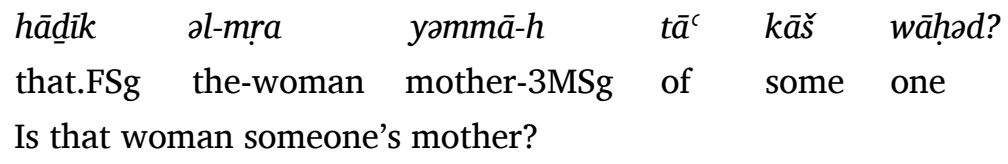

Note that, whereas in Levantine Arabic the particle that intervenes between the possessor and possessed in doubling constructions is the dative $l$-, here the particle used is the same as that found in non-doubled genitives. Note also that, unlike in Levantine Arabic, the possessed item must be a kinship term to be doubled; as A. FISCHER (1907: 183), and later OSTOYA-DELMAS (1938: 81), perceptively note, forms such as:

$$
\begin{array}{lll}
\text { *rajl-i-h } \quad d d \bar{\imath} & x \bar{u}-y a \\
\text { foot-PL-3MSg of } & \text { brother-1SgGen } \\
\text { *my brother's feet } &
\end{array}
$$

are rejected without hesitation.

Indirect object doubling has not previously been documented in the region, but is frequent in the dialect of Dellys (north-central Algerian coast), spoken by this author. While possible with most verbs taking indirect objects, it is particularly common with the verb "say", :

\begin{tabular}{lrl} 
qul-t-lu $\quad l-b \bar{a} b a$ & $l b \bar{a} r \partial h$ \\
say-1Sg-3MSgDat & to-father & yesterday \\
\multicolumn{2}{l}{ I told my father yesterday: (...) } &
\end{tabular}

For indirect objects in this dialect - unlike in documented Levantine varieties - doubling is possible not only with definites but even with non-specific indefinites; the following example, for instance, is entirely impossible in Lebanon (SAMIA NAÏM, p.c.):

$\begin{array}{llll}\text { 21) } m \bar{a} \quad t \text {-səm }{ }^{c}-\overline{-}-l u & \text { hatta } & \text { l-wāh̆d } \\ \text { not } & \text { 2-hear-FSg-3MSgDat } & \text { even } & \text { to-one } \\ \text { Don't listen to anyone. } & & \end{array}$


It is not, however, possible for direct objects, nor for the complements of prepositions other than dative "to", again unlike Levantine; examples such as the following are entirely unacceptable to Dellys speakers:

22)
$*$ šf $f-t-h a$
$(-) x^{w} t-i$
lbārạ
see-1SgPf-3FSgDO
(to-)sister-1SgGen
yesterday
*I saw my sister yesterday.

Both constructions thus contrast with their Levantine equivalents in their selectional restrictions, and the commoner one in the particle used as well.

In Berber, on the other hand, we find exactly the same two constructions with the same restrictions. In every documented Berber variety, the possessors of kinship terms are obligatorily doubled, while possessors of other nouns are not. In fact, bare kinship terms are interpreted in Berber as possessed by the speaker, ie by the 1 st person; to refer to non- $1^{\text {st }}$-person-possessed kin, their possessor must be explicitly marked, even if indefinite, and even if existence is not presupposed. (According to BOUCHERIT (1999), this is also true of Jijel Arabic, but not of other Maghrebi dialects that show doubling.) Thus in Kabyle:

23)

$\begin{array}{ll}\text { Tessid } & \text { gma-k? } \\ \text { 2Sg.have } & \text { brother-2MSgGen? }\end{array}$

Do you have a brother?

(OMAR MOUFFOK, http://tatoeba.org/deu/sentences/show/1736532)

24)

$\begin{array}{lllll}\text { yelli-s } & n & \text { yiwen } & n & \text { uzeddam } \\ \text { daughter-3SgGen } & \text { of } & \text { one } & \text { of } & \text { woodcutter }\end{array}$

a woodcutter's daughter

(Omar Mouffok, http://tatoeba.org/deu/sentences/show/1674690)

Just as in Maghrebi Arabic, the genitive marker $-n$ in Berber - obligatorily intervenes, and this particle is distinct from the dative marker, Berber $i$.

For indirect objects, in almost all northern Berber varieties, doubling is optional but extremely frequent, especially with the verb "say" (SOUAG 2014). As in Dellys, in Kabyle - socially and geographically the closest Berber variety to Dellys - definiteness is not a precondition for this process:

$\begin{array}{llllll}\text { Ayyer } & \text { ur } & \text { as-tessutured } i & \text { kra } & n & \text { yiwen... } \\ \text { why } & \text { not } & \text { 3SgDat-2Sg.ask to } & \text { some } & \text { GEN } & \text { one... }\end{array}$


Why don't you ask someone?

(Omar Mouffok, http://tatoeba.org/deu/sentences/show/1957789)

For direct objects and objects of prepositions, doubling has not been documented in Berber.

In short, the distribution of clitic doubling in those Maghrebi Arabic varieties which have it differs in its syntactic contexts and selectional restrictions from its distribution in Levantine Arabic, but is identical in both respects to its distribution in Northern Berber. The presence of clitic doubling in Maghrebi Arabic can adequately be explained in terms of Berber substratum influence, and gives no reason to suppose that the first Arabic-speaking immigrants to North Africa brought with them a clitic-doubling Arabic dialect.

\subsection{Maltese}

Clitic doubling in Maltese is briefly mentioned in descriptions as early as SUTCLIFFE (1936: 179) and AQUILINA (1959: 335), but has been examined in more detail in recent years, ${ }^{3}$ e.g. CAMILLERI (2011: 149), SADLER CAMILLERI (2012), ČÉPLÖ (2014). The latter demonstrates that clitic doubling proper is attested, and, while leaving its exact function open, notes its frequency in "exclamations, exhortations, and especially questions". In Maltese, doubling occurs with definite direct objects:

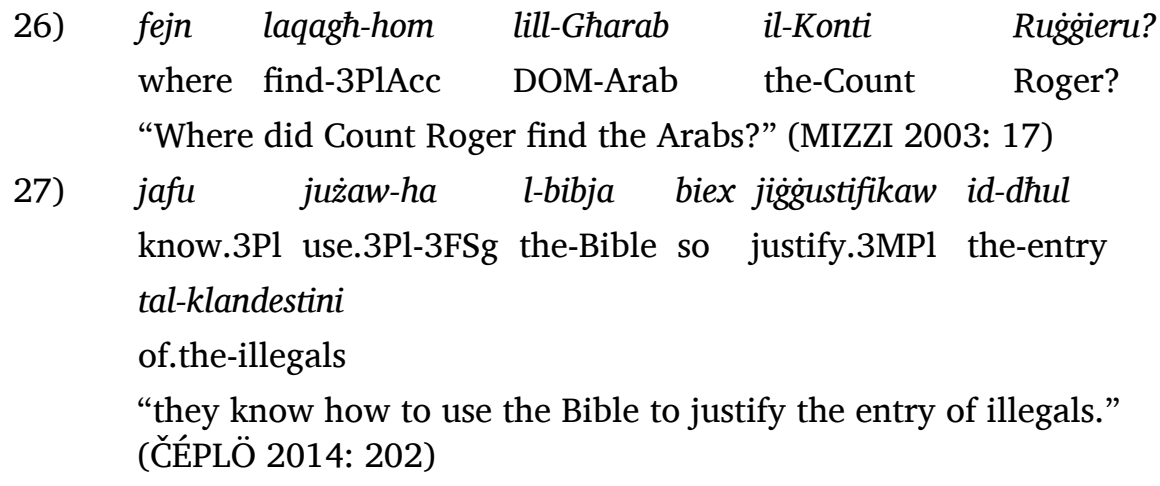

The definite article may be omitted, notably in pejorative contexts (FABRI 2011), but even when it is omitted the interpretation remains definite. As in Cyprus and Central Asia, the presence or absence of the marker lil- is suffi-

3 The directly relevant article of BORG - MIFSUD (2002) came to the author's attention only at this article's proofreading stage. 
ciently accounted for by animacy and definiteness, with no need to postulate a specific link to doubling; lil- is regular for specific human direct objects, and ungrammatical for inanimates.

Though hardly described in the literature, doubling is also attested in Maltese with indirect objects, eg:

28)

$\begin{array}{lll}\text { qal-lhom } & \text { lil } & \text { gurnalisti } \\ \text { said-3PIDat } & \text { to } & \text { journalists }\end{array}$

He told the journalists...

(http://zekzik.com/2013/04/01/kellna-ragun-marlene-hadet-over-

il-ministeru-tas-sahha/)

29)

$\begin{array}{ll}\text { U qal-lhom } & \text { lil-wejters: ... } \\ \text { and said-3PlDat } & \text { to-waiters }\end{array}$

And he told the waiters: ...

(http://www.ourladyofconsecration.org/media/lehen/girgenti\% 2095.pdf)

Doubling is not attested for possessors or objects of prepositions.

This distribution has little in common with any other Arabic variety examined, but closely resembles that found in Sicilian, which has profoundly influenced Maltese. In Sicilian, the dative preposition $a$ is used to mark human direct objects (IEMMOLO 2010) and all indirect objects irrespective of the presence or absence of doubling. There, doubling (by this article's definition; clitic right dislocation by CRUSCHINO'S) is obligatory for non-focused (and hence normally definite) arguments in WH-questions, be they direct objects:

$$
\begin{array}{lllllll}
\text { A } & c u & u & \text { detti } & u & \text { libbru } & \text { Mario? } \\
\text { to } & \text { who } & \text { 3MSgAcc } & \text { give.PAST.3Sg } & \text { the.MSg } & \text { book } & \text { Mario }
\end{array}
$$

Who did Mario give the book to? (ungrammatical without doubling; CRUSCHINO (2011: 45))

or indirect objects:

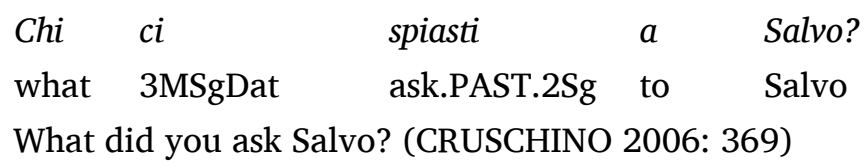


Doubling is likewise possible in declarative sentences, again for non-focused constituents, be they direct objects:

32)

$\begin{array}{lllll}u & \text { ammazzà } & \text { Alfiu } & a & \text { Turiddu. } \\ \text { 3MSgAcc } & \text { kill.PAST.3Sg } & \text { Alfiu } & \text { to } & \text { Turiddu. }\end{array}$

Alfiu killed Turiddu. (CRUSCHINO 2006: 39)

or indirect objects:

33)

$\begin{array}{llllll}\mathrm{Ci} & \mathrm{lu} & \text { detti } & a & m a & \text { frati. } \\ \text { 3MSgDat } & \text { 3MSgAcc } & \text { give.PAST.1Sg } & \text { to } & \text { my } & \text { brother }\end{array}$

I gave it to my brother. (PALERMO 1976: 27)

34)

E lu cuccu ci dissi a li ruccuotti

And the.MSg owl 3PlDat say.PAST.3Sg to the.MPl owlets

And the owl said to its owlets... (SCIASCIA 1998: 87)

The distribution of the case assigner, the contexts in which doubling occurs, and the syntactic roles which allow doubling in Maltese all match Sicilian better than they match Levantine Arabic, while no property of the Levantine Arabic construction matches Maltese better than Sicilian does. Maltese clitic doubling is thus better explained as the result of Sicilian superstratum influence than as a retention from some early stage of Arabic.

\subsection{Dhofar}

RHODOKANAKIS (1908:I: 205-206) describes Dhofar Arabic as allowing doubling in a number of contexts, and furnishes several examples. According to this source, doubling is rare but possible for direct objects, indirect objects, and the complements of prepositions - all the examples he gives are definite, and examination of their contexts indicates that their referents were previously mentioned and play prominent roles in the discourse. Possessor doubling is not attested in this source. The doubled direct object takes no marking, while other doubled objects double the preposition as well:

35) yi-gber-ûn-hā

ómm eṣ-ṣultân

3-bury-3MP1-3FSgDO mother the-sultan

They bury the sultan's mother. (ibid:I:47)

36)

$\begin{array}{llll}\bar{u} & \text { gál } & \text { l-ah } & \text { el-kebîr li-ș-ṣgîr } \\ \text { and } & \text { said.3MSg } & \text { to-3MSg } & \text { the-big to-the-small }\end{array}$

and the big one said to the little one (ibid:I:2) 
$\begin{array}{clllll}\text { 37) hené } & \text { šerâf } & \text { embaddiyin } & b \text {-hê } & \text { bĕ-bínt } & x \hat{u}-n \bar{a} \\ \text { we } & \text { sharifs } & \text { start.Ptcp.MPl } & \text { with-3FSg } & \text { with-daughter } & \text { brother-1Pl }\end{array}$ We are Sharifs, we have precedence with regard to our brother's daughter. (ibid:I:63)

For more than a century after RHODOKANAKIS' work, no further research was conducted on Dhofar Arabic. Recently, however, DAVEY (2013) has put together a grammar of Coastal Dhofar Arabic. This variety seems somewhat different from what Rhodokanakis recorded, and, according to DAVEY (p.c.), it was not observed to make any use of clitic doubling.

This difference can perhaps better be understood in light of the sources used. As DAVEY points out, RHODOKANAKIS' study was based mainly on the idiolect of a single Bedouin from Dhofar, Mhammed bin Selim ElKathiri. This speaker was bilingual in Jibbali (Shihri), and sociolinguistic considerations suggest that this was likely his first language. He also dictated texts in Jibbali to BITTNER (1916), which make it possible to compare his usage of clitic doubling across the two languages. The doubling of indirect objects and objects of prepositions is relatively frequent in these texts (BITTNER 1916:II: 53). For indirect objects, the construction is identical; for objects of prepositions, the preposition is normally doubled as in El-Kathiri's Arabic. Also as in his Arabic, no doubled possessors are found. Thus:

$\begin{array}{llll}\text { 'oñr } & \text { he-š } & \text { šéxer } & \text { l-embéra } \\ \text { said.3MSg } & \text { to-3MSg } & \text { old man } & \text { to-boy }\end{array}$

The old man said to the boy (BITTNER 1916:III: 78)

$\begin{array}{lll}\text { 'aréd } & \text { liš } & \text { le-ezír } \\ \text { sent.3MSg } & \text { on-3MSg } & \text { on-vizier }\end{array}$

He sent for the vizier. (BITTNER 1916:III: 58)

There is one example without doubling of the preposition, but this is perhaps better interpreted as right dislocation motivated by hesitation to use coarse words:

$\begin{array}{lll}\text { ben-í-sen, } & \text { eñqerért } & \text { be-'agríz } \\ \text { between-PL-3MPl, } & \text { anus } & \text { and-testicles }\end{array}$

between the anus and the testicles (BITTNER 1916:III: 48)

Moreover, one example of direct object doubling (with a ditransitive verb) was noted, showing the same construction as in his Arabic: 


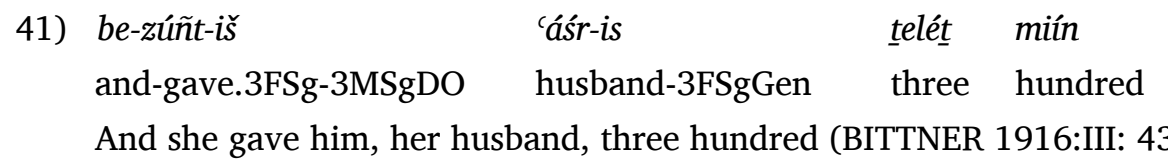

The parallels between this speaker's use of clitic doubling in Jibbali and in Arabic - already explicitly noted by RHODOKANAKIS - are too great to be coincidental; in effect, he seems to have been using the same clitic doubling constructions across both his languages. There is no published evidence for clitic doubling in Jibbali outside of El-Kathiri's idiolect, any more than in Dhofar Arabic - neither HOFSTEDE (1998) nor RUBIN (2014) mention it. Only further data can determine whether this is a general feature of some particular Dhofar dialect (perhaps the second language dialect of Arabic spoken by Shihri speakers?) or just an unusual feature of El-Kathiri's idiolect. However, if this construction was not simply idiolectal, its origins seem more likely to lie in Jibbali than in Dhofar Arabic, since no parallels have been found in any Arabic dialect of the Arabian peninsula.

\section{Conclusions}

The differences among the various constructions lumped together by the label of clitic doubling are large enough to make that label effectively irrelevant in arguing for contact or for common inheritance. What does count is the four parameters of clitic doubling: only if all four overlap substantially can a plausible case for a causal relationship be made. The application of this criterion indicates that contact with other languages has played an important - but not exhaustive - role in the emergence of clitic doubling in Arabic dialects, and that clitic doubling has emerged at least four times in Arabic dialects independently of one another. More data on Cyprus and Dhofar would be desirable, but would not change the overall conclusions. We may conclude that Arabic speakers find it relatively easy to calque clitic doubling under appropriate conditions. The known sociolinguistic history of the regions which have calqued it, however, suggests that the conditions in question are relatively restrictive, corresponding to VAN COETSEM'S (1988) "imposition". Minimally, such a calque presupposes widespread fluency in the source language, and in many - though not all - cases this condition is realised through the speech community having formerly spoken that language rather than Arabic. 


\section{References}

ANAGNOSTOPOULOU, E. (1999): Conditions on clitic doubling in Greek. In: RIEMSDIJK, H. C. VAN (ed.): Clitics in the Languages of Europe. Berlin: Mouton de Gruyter.

AOUN, J. (1981): The Formal Nature of Anaphoric Relations. MIT PhD thesis.

AOUN, J. (1993): The syntax of doubled arguments. In: International Journal of Basque Linguistics and Philology 27(3): 709-730.

AOUN, J. (1999): Clitic-doubled arguments. In: JOHNSON, K. - ROBERTS, I. (eds.): Beyond Principles and Parameters: Essays in memory of Osvaldo Jaeggli. Dordrecht: Kluwer Academic Publishers, 15-42.

AOUN, J. (2011): Clitic. In: EDZARD, L. - DE JONG, R. (ed.): Encyclopedia of Arabic Language and Linguistics. http://referenceworks.brillonline.com/ entries/encyclopedia-of-arabic-language-and-linguistics/clitic-

EALL_COM_0059 (2 March, 2015).

AQUILINA, J. (1959): The Structure of Maltese: A Study in Mixed Grammar and Vocabulary. Valletta: Royal University of Malta.

ARKADIEV, P. (2010): Clitic doubling: Towards a typology. Paper presented at the Workshop on Clitics and Syntactic Typology. http://www.inslav.ru/ images/stories/people/arkadiev/Arkadiev_cldoubling_rggu2010.pdf.

BITTNER, M. (1916): Studien zur Šhauri-Sprache in den Bergen von Dofâr am Persischen Meerbusen. Vienna: Alfred Hölder.

BLANC, H. (1964): Communal Dialects in Baghdad. (Harvard Middle Eastern Monographs 10). Cambridge: Harvard University Press.

BLAU, J. (1967): A Grammar of Christian Arabic Based Mainly on SouthPalestinian Texts from the First Millennium. Vol. 276. (Corpus Scriptorum Christianorum Orientalium). Louvain: Secrétariat du CorpusSCO.

BORG, A. (1984): Kormakiti Arabic: Phonological notes and texts. In: Zeitschrift für Arabische Linguistik 13: 68-85.

BORG, A. (1985): Cypriot Arabic. Stuttgart: Deutsche Morgenländische Gesellschaft.

BORG, A. (2004): A Comparative Glossary of Cypriot Maronite Arabic (ArabicEnglish): With an Introductory Essay. (Handbuch der Orientalistik 70). Leiden: Brill.

BORG, A. - MIFSUD, M. (2002): Maltese object marking in a Mediterranean context. In: RAMAT, P. - STOLZ, T (eds.): Mediterranean languages. Pa- 
pers from the MEDTYP workshop, Tirrenia, June 2000. Bochum: Brockmeyer, 33-46.

BOUCHERIT, A. (1999): Relation d'appartenance, nom de parenté et substrat berbère. In: LAMBERTI, M. and TONELLI, L. (ed.): Afrosiatica Tergestina. Papers from $9^{\text {th }}$ Italian Meeting of Afro-Asiatic (Hamito-Semitic) Linguistics. Padova: Unipress, 175-186.

BOSSONG, G. (1998): Le marquage différentiel de l'objet dans les langues d'Europe. In: FEUILLET, J. (ed.), Actance et valence dans les langues de l'Europe. Berlin: Mouton de Gruyter, 193-258.

BROCKELMANN, C. (1982): Grundriss der vergleichenden Grammatik der semitischen Sprachen. Hildesheim: Georg Olms.

BRUSTAD, K. E. (2000): The Syntax of Spoken Arabic: A comparative study of Moroccan, Egyptian, Syrian, and Kuwaiti dialects. Georgetown: Georgetown University Press.

CAMILLERI, M. (2011): On pronominal verbal enclitics in Maltese. In: CARUANA, S. - FABRI, R. - STOLZ, TH. (eds.): Variation and Change: The Dynamics of Maltese in Space, Time and Society. Berlin: Akademie, 131-156.

CAMILLERI, M. - SADLER L. (2012): On the analysis of non-selected datives in Maltese. In: BUTT, M. - HOLLOWAY KING, T. (eds.): Proceedings of the LFG12 Conference. Stanford: CSLI Publications.

ČÉPLÖ, S. (2011): Object reduplication in Maltese. Paper presented at the GHILM $3^{\text {rd }}$ Conference on Maltese Linguistics, Malta.

ČÉPLÖ, S. (2014): An overview of object reduplication in Maltese. In: BORG, A. - CARUANA, S. - VELLA, A. (eds.): Perspectives on Maltese Linguistics. Berlin: Akademie, 201-223.

CHATZIKYRIAKIDIS, S. (2010): Clitics in Four Dialects of Modern Greek: A Dynamic Account. London: King's College, University of London PhD thesis.

http://www.stergioschatzikyriakidis.com/uploads/1/0/3/6/10363759/

chatzikyriakidis-phdthesis.pdf.

CHIKOVANI, G. (2002): Kaškadariuli dialeqti (fonologia, gramatika, leqsika). Tbilisi: Georgian Academy of Sciences.

CHIKOVANI, G. (2003): Central Asian Arabic dialects: The main peculiarities. In: FERRANDO, I. - SANCHEZ SANDOVAL, J. J. (eds.), AIDA $5^{\text {th }}$ Confer-ence Proceedings, Cádiz, September 2002. Cádiz: Universidad de Cádiz, 1-12. 
CHIKOVANI, G. (2005): Linguistic contacts in Central Asia. In: CSATÓ, É. Á. JAHANI, I. \& C. (eds.): Linguistic convergence and areal diffusion: case studies from Iranian, Semitic and Turkic. London: RoutledgeCurzon, 127-132.

COETSEM, F. VAN (1988): Loan phonology and the two transfer types in language contact. (Publications in Language Sciences 27). Dordrecht: Foris.

COGHILL, E. (2014): Differential object marking in Neo-Aramaic. Linguistics 52(2). 335-364.

CONTINI, R. (1999): Le substrat araméen en néo-arabe libanais: Préliminaires à une enquête systématique. In: LAMBERTI, M. - TONELLI, L. (eds.): Afroasiatica Tergestina: Papers from the $9^{\text {th }}$ Italian Meeting of AfroAsiatic (Hamito-Semitic) Linguistics. Trieste, April 23-24, 1998. Padova: Unipress, 101-122.

CORRELL, CH. (1978): Untersuchungen zur Syntax der neuwestaramäischen Dialekte des Antilibanon: (Ma`lūla, Baȟ`a, Ğubb`Adīn): mit besonderer Berückssichtigung der Auswirkungen arab. Adstrateinflusses: nebst zwei Anhängen zum neuaramäischen Dialekt von Ğubb`Adin. (Abhandlungen für die Kunde des Morgenlandes 44/4). Mainz: Deutsche Morgenländische Gesellschaft.

COWELL, M. W. (1964): A Reference Grammar of Syrian Arabic: Based on the dialect of Damascus. Washington: Georgetown University Press.

CRUSCHINA, S. (2011): Discourse-Related Features and Functional Projections. (Oxford Studies in Comparative Syntax). Oxford: Oxford University Press.

CRUSCHINO, S. (2006): Informational focus in Sicilian and the left periphery. In: FRASCARELLI, M. (ed.): Phases of Interpretation. Berlin: Mouton de Gruyter, 363-385.

DAVEY, R. J. (2013): Coastal Dhofārī Arabic: A sketch grammar. Manchester. University of Manchester PhD thesis.

https://www.escholar.manchester.ac.uk/uk-ac-man-scw:199131.

DIEM, W. (1979): Studien zur Frage des Substrats im Arabischen. In: Der Islam 56(1): 12-80.

ERWIN, W. M. (1963): A Short Reference Grammar of Iraqi Arabic. (Richard Slade Harrell Arabic Series 04). Washington D.C: Georgetown University Press.

FABRI, R. (2011): Clitics and non-definite NPs in Maltese. Talk. Paper presented at the GHILM $3^{\text {rd }}$ Conference on Maltese Linguistics, University of Malta, Valletta.

http://www.um.edu.mt/_data/assets/pdf_file/0007/123991/ray.fabri.pdf. 
FÉGHALI, M. T. (1928): Syntaxe des parlers arabes actuels du Liban. Paris: Imprimerie Nationale.

FISCHER, A. (1907): Eine interessante algerisch-marokkanische Genetivumschreibung. In: Zeitschriften der Deutschen Morgenländischen Gesellschaft 61: 178-195.

FISCHER, A. (1909): II. In: Zeitschrift der Deutschen Morgenländischen Gesellschaft 61. 825-827.

GELDEREN, E. VAN (2011): The Linguistic Cycle: Language Change and the Language Faculty. New York: Oxford University Press.

GIVÓN, T. (1976): Topic, Pronoun, and Grammatical Agreement. In: LI, CH. N. (ed.): Subject and Topic. New York: Academic Press.

GUELLA, N. (2011): Possessive Constructions in Arabic: A Cross-dialectal Study. http://faculty.ksu.edu.sa/nguella/Documents/Possessive\%20 Constructions\%20in\%20Arabic.pdf (20 February, 2013).

ABU-HAIDAR, F. (1979): A Study of the Spoken Arabic of Baskinta. (James G. Furlong Fund v. 28). Leiden: Brill, for the Royal Asiatic Society.

ABU-HAIDAR, F. (1991): Christian Arabic of Baghdad. (Semitica Viva 7). Wiesbaden: Harrassowitz.

HARRELL, R. S. (1962): A Short Reference Grammar of Moroccan Arabic. (Richard Slade Harrell Arabic Series 01). Washington, DC: Georgetown University Press.

HEATH, J. (2002): Jewish and Muslim Dialects of Moroccan Arabic. (RoutledgeCurzon Arabic Linguistics Series). London: RoutledgeCurzon.

HEATH, J. (2015): D-possessives and the origins of Moroccan Arabic. In: Diachronica 32(1): 1-33.

HOFSTEDE, A. I. (1998): Syntax of Jibbali. University of Manchester Doctoral thesis.

HOPKINS, S. (1997): On the construction šmēh l-gabrā 'the name of the man' in Aramaic. In: Journal of Semitic Studies 42(1): 23-32.

IDO, S. (2007): Bukharan Tajik. Munich: LINCOM Europa.

IEMMOLO, G. (2010): Topicality and differential object marking: Evidence from Romance and beyond. In: Studies in Language 34(2): 239-272.

JAEGGLI, O. (1982): Topics in Romance Syntax. Dordrecht: Foris.

JASTROW, O. (1979): Zur arabischen Mundart von Mossul. In: Zeitschrift für Arabische Linguistik 2: 36-75. 
JASTROW, O. (1988): Zum arabischen Dialekt der Juden von Arbīl. In: Zeitschrift für Arabische Linguistik 19: 50-59.

JASTROW, O. (1990): Der arabische Dialekt der Juden von 'Aqra und Arbïl. Wiesbaden: Harrassowitz.

JOHNSTONE, Th. M. (1975): The Spoken Arabic of Tikrit. In: Annual of Leeds University Oriental Society 7: 89-109.

JOOSTEN, J. (1996): The Syriac Language of the Peshitta \& Old Syria Versions of Matthew: Syntactic Structure, Inner-Syriac Developments \& Translation Technique. Leiden: Brill.

KALLULLI, D. (2001): Direct Object Clitic Doubling in Albanian and Greek. In: RIVERO, M. L. - RALLI, A. (eds.): Comparative Syntax of Balkan Languages. Oxford: Oxford University Press.

KHAN, G. (1984): Object Markers and Agreement Pronouns in Semitic Languages. In: Bulletin of the School of Oriental and African Studies 47: 468-500.

KOUTSOUDAS, A. (1967): Object Particles in Lebanese. In: Journal of the American Oriental Society 87(4): 512-517. doi:10.2307/597592 (25 October, 2013).

LANDBERG, C. (1883): Proverbes et dictons de la province de Syrie. (Proverbes et dictons du peuple arabe v. 1). Leiden: E.J. Brill.

LEVIN, A. (1987): The Particle $l a$ as an object marker in some Arabic dialects of the Galilee. In: Zeitschrift für Arabische Linguistik 17: 31-40.

LUCIANI, D. (1889): Les Ouled Athia de l'Oued Zhour. In: Revue Africaine 195: 296-311.

MALAIKA, N. (1963): Grundzüge der Grammatik des arabischen Dialektes von Bagdad. Wiesbaden: Harrassowitz.

MARÇAIS, PH. (1936): Remarques sur un fait syntaxique du parler arabe d'El-Milia. In: Revue Africaine 79(2): 1047-1055.

MARÇAIS, PH. (1952): Le parler arabe de Djidjelli (nord constantinois, Algerie).

MARÇAIS, PH. (1977): Esquisse grammaticale de l'arabe maghrébin. Paris: Maisonneuve.

MARÇAIS, W. (1902): Le dialecte arabe parlè á Tlemcen: grammaire, textes et glossaire. (Publications de l'École des Lettres d'Alger 26). Paris: E. Leroux.

MARÇAIS, W. - GUIGA, A. (1925): Textes arabes de Takroûna: I transcription, traduction annotée, glossaire. Paris: Imprimerie: Bibliothèque de l'École des Languages Orientales Vivantes. 
MELCER, I. (1995): The Analytical Genitive in the Jewish-Baghdadi Arabic Dialect. In: Zeitschrift für Arabische Linguistik 29: 59-76.

MIZZI, P. (2003): Il-Kuluri ta' Malta. (Leġgendi Maltin). Santa Venera: Klabb Kotba Maltin.

MOHAMMAD, M. A. (2000): Word order, agreement, and pronominalization in standard and Palestinian Arabic. (Amsterdam Studies in the Theory and History of Linguistic Science v. 181). Amsterdam; Philadelphia: J. Benjamins.

MORIMOTO, Y. (2002): Prominence Mismatches and Differential Object Marking in Bantu. In: BUTT, M. - HOLLOWAY KING, T. (eds.): Proceedings of the LFG02 Conference. Stanford: CSLI.

MURAOKA, T. (1998): A Grammar of Egyptian Aramaic. (Handbuch der Orientalistik Bd. 32). Leiden: Brill.

NAÏM, S. (2009): Possessive genitive, dative construction and TAM Categories. In: WATSON, J. - RETSÖ, J. (eds.): Relative Clauses and Genitive Constructions in Semitic. Oxford: Oxford University Press.

NAÏM, S. (2011): Dialects of the Levant. In: Weninger, S. (ed.): Handbook of Semitic languages. Berlin: Mouton de Gruyter.

NÖLDEKE, TH. (1904): Compendious Syriac grammar: Translated from the second German edition by James A. Crichton. London: Williams and Norgate.

OSTOYA-DELMAS, S. (1938): Notes préliminaires à l'étude des parlers de l'arrondissement de Philippeville. In: Revue Africaine 82: 60-83.

PALERMO, J. (1976): Il problema del siciliano. Alcune isoglosse ibero-siciliane relevanti. In: VÀRVARO, A. (ed.): XIV Congresso Internazionale di Linguistica e Filologia Romanza, Napoli, 15-20 Aprile 1974. Napoli/ Amsterdam: Macchiaroli/Benjamins, 17-29.

POPPE, N. (1962): Uzbek newspaper reader: with glossary. (Indiana University Publications 010). Bloomington: Indiana University Press.

RATCLIFFE, R. (2005): Bukhara Arabic: A Metatypized Dialect of Arabic in Central Asia. In CSATÓ, É. Á. - JAHANI, I. \& C. (eds.): Linguistic Convergence and Areal Diffusion: Case studies from Iranian, Semitic and Turkic. Psychology Press, 141-151.

RHODOKANAKIS, N. (1908): Der vulgärarabische Dialekt im Dofâr (Zfâr). Wien: A. Hölder.

RUBIN, A. D. (2014): The Jibbali (Shahri) language of Oman: grammar and texts. (Studies in Semitic Languages and Linguistics 72). Leiden: Brill. 
SCHATTNER-RIESER, U. (2004): L'araméen des manuscrits de la mer Morte:

1. Grammaire. Lausanne: Editions du Zèbre.

SCIASCIA, L. (1998): Il giorno della civetta. (Ed.) Gerard Slowey. (Italian Texts). Manchester: Manchester University Press.

SHLONSKY, U. (1997): Clause Structure and Word Order in Hebrew and Arabic: An Essay in Comparative Semitic Syntax. (Oxford Studies in Comparative Syntax). Oxford: Oxford University Press.

SOUAG, L. (2005): Notes on the Algerian Arabic Dialect of Dellys. In: Estudios de Dialectología Norteafricana y Andalusí 9.

SOUAG, L. (2014): The development of dative agreement in Berber: beyond nominal hierarchies. In: Transactions of the Philological Society. Early View. doi:10.1111/1467-968X.12049 (2 March, 2015).

SUÑER, M. (1988): The role of agreement in clitic-doubled constructions. In: Natural Language and Linguistic Theory 6: 391-434.

SUTCLIFFE, E. F. (1936): A Grammar of the Maltese Language. London: Oxford University Press.

VINNIKOV, I. N. (1969): Jazyk i fol'klor Buxarskix Arabov. Moscow: Nauka.

WENINGER, S. (2011): Aramaic-Arabic language contact. In: WENINGER, S. (ed.): The Semitic Languages: An International Handbook. Berlin: De Gruyter Mouton.

WHITEHEAD, J. D. 1978: Some distinctive features of the language of the Aramaic Arsames correspondence. In: Journal of Near Eastern Studies 37(2): 119-140. 